IRA-International Journal of Management \& Social Sciences

ISSN 2455-2267; Vol.06, Issue 03 (2017)

Pg. no. 500-508

Institute of Research Advances

https://research-advances.org/index.php/RAJMSS

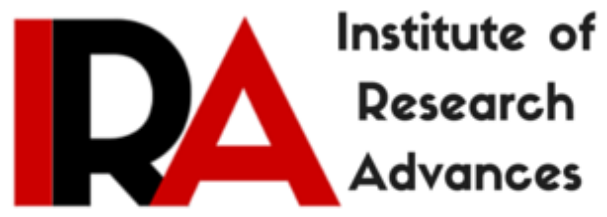

\title{
Testing the Random Walk Theory in the Nigerian Stock Market
}

\author{
Clement C. M. Ajekwe ${ }^{1}$, Adzor Ibiamke ${ }^{2}$, Habila Abel Haruna ${ }^{3}$ \\ ${ }^{1}$ Department of Accounting, Benue State University Makurdi, Nigeria. \\ ${ }^{2}$ Department of Accounting, Benue State University Makurdi, Nigeria. \\ ${ }^{3}$ Department of Banking and Finance, Federal University Wukari, Nigeria.
}

Type of Review: Peer Reviewed.

DOI: http://dx.doi.org/10.21013/jmss.v6.n3.p15

\section{How to cite this paper:}

Ajekwe, C., Ibiamke, A., \& Haruna, H. (2017). Testing the Random Walk Theory in the Nigerian Stock Market. IRA-International Journal of Management \& Social Sciences (ISSN 2455-2267), 6(3), 500-508. doi:http://dx.doi.org/10.21013/jmss.v6.n3.p15

(C) Institute of Research Advances

(cc) EY-NG

This work is licensed under a Creative Commons Attribution-Non Commercial 4.0 International License subject to proper citation to the publication source of the work.

Disclaimer: The scholarly papers as reviewed and published by the Institute of Research Advances (IRA) are the views and opinions of their respective authors and are not the views or opinions of the IRA. The IRA disclaims of any harm or loss caused due to the published content to any party. 


\begin{abstract}
This study tests the random walk theory in the Nigerian stock market by analyzing whether stock returns follow a random walk distribution. The study employs the daily returns of the Top 20 most performing stocks on the NSE for the period January $1^{\text {st }} 2010$ to December $31^{\text {st }} 2014$. Autocorrelation and runs test were employed for hypothesis testing. Based on our analysis, we found that the daily stock returns of the 20 most active stocks on the Nigerian stock market are randomly distributed indicating that Nigerian Stock market is informational efficient at the weak form level. The implication of the finding is that no one can fool the market consistently for a long time by trading on the basis of past information such as historical stock prices. The study recommends that more efforts should be made to reposition the market to attract more investible funds from domestic and foreign investors.
\end{abstract}

Key Words: Capital Market, Efficiency level, Nigerian Stock Exchange, random walk

\title{
1. Introduction
}

Efficiency of markets has been a matter of considerable interest in the finance literature since the introduction of Efficient Market Hypothesis (EMH) by Eugene Fama in 1965. Although market efficiency are of three types: (Allocation efficiency, operational efficiency and informational or pricing efficiency), the informational efficiency which is the behaviour of share prices and returns in relation to the arrival of information in the market is the most widely studied, and as it generate the most interest. Under informational efficiency prices provide accurate signals for resource allocation so that firms can make productive investment decision and investors can choose among the securities under the assumption that securities' prices at any time fully reflect all available information.

The efficiency of the stock market is imperative in economic development as it provides the vehicle for mobilizing savings and investment resources for developmental purposes. It also affords investors opportunities to diversify their portfolio across a variety of assets leading to reduction in the cost of capital.

Although information efficiency has been widely investigated (Shafi, 2014; Ayentimi, Mensah \& Naa-idar, 2013; Simons \& Laryea, 2006), recent developments have created an illusion that market efficiency will improve. In emerging stock markets, most empirical studies focused on weak form efficiency (Afego, 2012; Gimba, 2012; Ayadi, 1984) which is the lowest out of the three forms of informational efficiency. In Nigeria, the Nigerian Stock Exchange (NSE) has witnessed tremendous growth in market capitalization, membership, value and volume traded as well as a tremendous improvement in the information flow using information technology in recent times (Tijjani, 2010). There has also been astronomic rise of the All Share Index (ASI) indicating investors' confidence in the stock market giving rise to the idea that its pricing efficiency might improve.

The main objective of this paper is to test the random walk theory in the NSE market in order to assess whether it is weak form efficient. The paper is organised in four sections, the next section is a review of literature; section 3 is the methodology adopted to address the problem; section 4 is data analysis and results; and finally conclusion and recommendation are presented in section 5 .

\section{Literature Review}

Market efficiency is a fundamental concept in finance; the concept was first introduced by Louis Bachelier in 1900 in his thesis title the "the random character of stock market prices" (Dimson \& Mussavian, 1998). The concept has since been refined into Efficient Market Theory (EMT). EMT posits that all information (past, present and even discounted future events) are reflected in market price in an efficient market (Fama, 1991). The concept of market efficiency has three different types (Brown, 2011); first an efficient market is a market in which resources are allocated to the most deserving entities- "allocational efficiency". Efficient market also means a market where the cost of operation in it and the time taken to execute a deal is minimal- "operational efficiency". The third and most important type of market efficiency is the "information or pricing efficiency". Information efficiency is a market in which prices provide accurate signals for the allocation of resources. In this market security prices always "fully reflect" available information. In an efficient market therefore, 
current stock prices fully reflect all available information about the value of the firm; in that way no one can fool the market by consistently making abnormal profits using public or even privately held information. Fama (1991) posits that the level of information efficiency in the stock markets including sophistication were not the same. He therefore considers market efficiency at three different forms or levels.

\section{a. Weak-form efficiency}

The weak-form of the market efficiency asserts that the current price of shares fully incorporates all past information such as historical prices. Thus, nobody can detect mispriced securities and consistently beat the market for long time by analyzing past prices. The weak form efficiency got its name for the reason that security prices are the most public as well as the most easily available pieces of information (Clarke, Jandik \& Mandelker, 2000). According to the weak form efficiency there will be no need for trend analysis since security prices follow a random walk. That is, trends cannot be predicted, thus, knowledge about the past cannot not help in realizing future returns.

\section{b. Semi-strong form efficiency}

The semi-strong-form of market efficiency suggests that the current price fully impound all information in the public domain (past and current information). Public information includes not only past prices, but also data reported in a company's financial statements (annual reports, income statements, periodic filings for the regulatory/governmental authorities such as SEC), earnings and dividend announcements, announced merger plans, the financial situation of company's competitors, expectations regarding macroeconomic factors such as inflation and unemployment. It is expected that markets cannot be efficient at the semi form except it is first proven efficient in the weak form.

\section{c. Strong form efficiency}

The strong form of market efficiency states that the current price fully incorporates all existing information; both public and even privately held (sometimes called insider information). In other words, the strong form market efficiency asserts that even a company's management (insiders) cannot systematically gain from inside information by buying company's shares to follow what they see as a very profitable purchase. Similarly, the members of the company's research department are not able to profit from the information about the new discovery they just completed. The rationale for strongform market efficiency is that the market anticipates, in an unbiased manner, future developments and therefore the share price incorporate all available information and evaluates it in a much more objective and informative way than the insiders. The three levels of market efficiency suggest that investing is a fair game in which "you win some" and "you lose some".

To what extent this is obtainable in Nigeria is tested in this paper with a focus on the weak-form level of informational efficiency. As earlier stated the weak form level is the first level of efficiency and that these levels are like the stair case; without attaining the lower (weak form) it is impossible to attain the next level of efficiency (semi-strong and the strong in that order).

This paper adopts a random walk theory as a basis for hypothesising. The theory suggests that share prices changes have the same distribution and are independent of each other, so that the past movement or trend of a share price or returns cannot be used to predict its future price or returns movement. The Random Walk model can be algebraically stated as follows:

$$
p_{t}=p_{t-1}+e_{t+1}
$$

Where

$\mathrm{P}_{\mathrm{t}}$ is price in year ${ }_{t}$ and $\mathrm{P}_{\mathrm{t}-1}=$ price in year ${ }_{\mathrm{t}-1}$.

According to equation (1), price changes must be a response only to new information; since information arrives randomly, share prices must also fluctuate unpredictably. The suggestion is that profiting from price prediction is very difficult and unlikely. The main idea behind this is that price changes with the arrival of new information. A market is said to be efficient if prices adjust quickly and, on average, without bias to new information. 
Fama (1970) argued that the random walk theory is an extension of the expected return or fair game model. Specifically, the fair game model indicates that the condition for having market equilibrium can be stated in terms of expected returns while the random walk model gives the details of the stochastic process generating returns. Therefore, he concluded that empirical tests of the random walk theory are more powerful in support of the EMH than tests of the fair game model.

\section{Empirical Review}

The work of Samuel and Yacout (1981) is the first published empirical studies on the weak-form efficiency of the Nigerian stock market. The study "Stock market in developing countries" employed serial correlation test to examine weekly price series of 21 listed Nigerian Firms from July 1977 to July 1979. The results show that the stock price changes are not serially correlated but follow a random walk, thus accepting the weak-form market efficiency hypothesis.

Ayadi (1984) followed Samuel and Yacout (1981) and work tested the price behaviour of 30 securities quoted on the NSE between 1977 and 1980, using Monday closing prices of these shares after adjusting for cash dividends and script issues. The results show that the share price movements on the NSE follow a random walk.

Olowe (1999), carries out tests of weak form efficiency in Nigeria using monthly data on 59 randomly selected securities from 1981-1992. He finds the Nigerian market to conform to weak-form efficiency in joint Q-tests of partial autocorrelation coefficients for ten lags in the return data, though he argues that poor informational flows and inefficient communications systems cast doubts on the ability of the market to pass higher hurdles of efficiency. More recent works of Okpara (2010) also provide evidence that the Nigerian stock market is weak-form efficient.

Okpara (2010) employed the runs test and the partial autocorrelation function as alternate forms of research instrument to test the weak form efficiency of the Nigerian stock market. His results revealed that the Nigerian stock market is efficient in the weak form and therefore follows a random walk process. He concluded that the opportunity of making excess returns using fundamental or technical analysis is not possible in Nigeria.

Contrary to the already cited works above, Akpan (1995) studied the informational efficiency of the NSE including the risk implications of investing in the market, using time series data of stock market price indices covering period of 1989 to 1992 . His result shows evidence to reject the hypothesis of weak form efficiency of NSE.

Nwosa and Oseni (2011) also investigated the weak-form efficient market hypothesis in Nigeria using a sample data from 1986 - 2010. Adopting a serial auto-correlation and regression method of analysis, they tested for stationarity using the Augmented Dickey Fuller and Philip Perron test. The result showed that the variables are stationary at first differencing. The result of the serial auto-correlation and regression analysis both revealed that the Nigeria stock market is informational inefficient, that is stock prices do not exhibit random walk.

Gimba (2012) tested the weak form of market efficiency for the market index and five selected individual stocks using weekly return data for the period of January 2007 to December 2009. Gimba (2012) employed three different techniques which include autocorrelation, runs and variance ratio tests. The results obtained from the autocorrelation indicate that the null hypothesis of random walk conclusively rejected the market index and four out of the five selected individual stocks, even where the returns were corrected for thin trading. The runs test and the variance ratio test under both homoscedasticity and hetroscedasticity assumptions also failed to support the random walk hypothesis for market index and all the selected individual stocks. Thus, he concluded that the Nigerian stock market is weak -form inefficient. Similar results are found by Afego (2012).

Similar to other emerging markets, studies in Nigeria show conflicting evidence. To reposition the market for global competition and enhance informational efficiency, many reforms have been done by the NSE market including market digitization to promote prompt information transmission, and the establishment of securities tribunal to prosecute erring members and participants in the market. In the light of these new happenings in the Nigerian market, it is expected that the market will now be 
efficient at least at the lower level. This study substantiates this claim using more recent information from 1st January 2010 to 31st December 2014. The study also employs both the non-parametric and parametric tests to provide a more comprehensive and robust conclusions regarding informational efficiency of the Nigerian Market.

\section{Methodology}

This study covers a period from January $1^{\text {st }} 2010$ to December, $31^{\text {st }} 2014$ for the Top 20 most performing and actively traded stocks on the main floor of the NSE. The selected Top 20 performing stocks is presented in Table 1.

Table 1: Top 20 Most Performing Stocks on Turnover in Nigeria

\begin{tabular}{|l|l|l|}
\hline S/No & \multicolumn{1}{|c|}{ COMPANY } & \multicolumn{1}{c|}{ Value (N) } \\
\hline 1 & ZENITH BANK & $625,937,687.46$ \\
\hline 2 & NIGERIAN BREWERIES & $608,568,186.05$ \\
\hline 3 & GUARANTY TRUST BANK & $324,524,872.79$ \\
\hline 4 & GUINNESS NIG. PLC & $274,111,449.90$ \\
\hline 5 & ACCESS BANK & $272,258,986.71$ \\
\hline 6 & UNITED BANK FOR AFRICA & $95,045,407.63$ \\
\hline 7 & UNILEVER & $62,248,768.42$ \\
\hline 8 & FIRST BANK OF NIGERIA HOLDING & $55,179,668.10$ \\
\hline 9 & FORTE OIL & $37,460,508.99$ \\
\hline 10 & UCAP & $36,774,410.02$ \\
\hline 11 & NESTLE PLC & $26,760,219.52$ \\
\hline 12 & OANDO PLC & $22,798,682.34$ \\
\hline 13 & DIAMOND BANK PLC & $10,344,981.89$ \\
\hline 14 & STANBIC IBTC & $8,221,515.42$ \\
\hline 15 & UACN & $6,781,483.73$ \\
\hline 16 & LARFARGE WAPCO & $5,905,322.45$ \\
\hline 17 & TRANSCORP & $5,861,402.49$ \\
\hline 18 & FLOURMILL & $5,759,028.08$ \\
\hline 19 & STERLIN BANK & $5,097,447.75$ \\
\hline 20 & FIDELITY BANK & $3,291,300.31$ \\
\hline
\end{tabular}

The daily all shares price is the main data required for analysis and is obtained from the NSE. To test the weak form efficiency of the NSE the daily returns determined by taking a natural logarithmic transformation was employed. The time series of continuously compounded daily returns are computed as follows:

$$
\mathrm{R}_{\mathrm{t}}=\frac{\left(p_{t}-p_{t-1}\right)}{p_{t-1}}=\log (\mathrm{r}) / \log \left(\mathrm{P}_{\mathrm{t}-1}\right)=\log (\mathrm{r})-\log \left(\mathrm{P}_{\mathrm{t}-1}\right)
$$

The degree of randomness in stock returns in Nigeria was tested using autocorrelation and runs test. Serial correlation or autocorrelation measure the correlation between different points in time. A relatively high serial correlation indicates the predictability in stock returns. There are several ways of testing for autocorrelation; the Ljung-Box Q-statistics which is widely used to test the weak form efficiency is adopted in this study. If there is no serial correlation in the residuals, the autocorrelations (AC) and partial autocorrelations (PAC) at all lags should be nearly zero, and all $Q$-statistics should be insignificant with large $p$-values. In the event where data is suspected to be non-normally distributed the runs tests is the most appropriate measure of random walk in stock prices or returns. For this reason the runs test was performed to complement the Ljung-Box Q statistics. According to $\mathrm{Li}$ (2008), serial correlation in stock returns is a necessary but not sufficient condition of market efficiency hence needs a complementary test such as the runs test.

\section{Analysis and Results}

The data for this research are empirically analysed and results reported and discussed in this section. The detailed results of the descriptive statistics for the daily share returns for the period from January $1^{\text {st }} 2010$ to $31^{\text {st }}$ December, 2014 are reported in Table 2. 
Table 2: Descriptive Statistics for the Daily Returns of the Sample Firms

\begin{tabular}{lrlrrrrrrr}
\hline & Mean & MAX & \multicolumn{1}{l}{ MIN } & \multicolumn{1}{l}{ SD } & \multicolumn{1}{l}{ SKEW } & \multicolumn{1}{c}{ KURT } & \multicolumn{1}{l}{ Jarque-Bera } & P-Value & N \\
\hline ACCESS & 0.0000 & 0.0417 & -0.0455 & 0.0107 & -0.0895 & 3.8129 & 35.6840 & 0.0000 & 1236 \\
DIAMOND & -0.0001 & 0.0414 & -0.0458 & 0.0118 & 0.0448 & 3.7440 & 28.9220 & 0.0000 & 1236 \\
FBNH & -0.0002 & 0.0419 & -0.0539 & 0.0100 & -0.0063 & 4.6557 & 141.1917 & 0.0000 & 1236 \\
FIDELITY & -0.0001 & 0.0411 & -0.0442 & 0.0115 & 0.0472 & 3.6453 & 21.9066 & 0.0000 & 1236 \\
FLOURMIL & 0.0000 & 0.0423 & -0.0747 & 0.0100 & -0.9467 & 10.4119 & 3013.8370 & 0.0000 & 1236 \\
FORTE & 0.0007 & 0.0424 & -0.0457 & 0.0125 & 0.4573 & 5.6404 & 402.1174 & 0.0000 & 1236 \\
GTB & 0.0002 & 0.0396 & -0.1137 & 0.0097 & -2.3885 & 31.6681 & 43501.1300 & 0.0000 & 1236 \\
GUINESS & 0.0001 & 0.0423 & -0.0397 & 0.0079 & 0.4447 & 7.7334 & 1194.6110 & 0.0000 & 1236 \\
NB & 0.0004 & 0.0273 & -0.0400 & 0.0082 & -0.1078 & 5.0537 & 219.6114 & 0.0000 & 1236 \\
NESTLE & 0.0005 & 0.0410 & -0.0895 & 0.0077 & -0.8043 & 23.0322 & 20799.6100 & 0.0000 & 1236 \\
OANDO & -0.0006 & 0.0423 & -0.1761 & 0.0148 & -1.5194 & 22.6021 & 20263.9900 & 0.0000 & 1236 \\
STANBIC & 0.0004 & 0.2487 & -0.0413 & 0.0123 & 6.6224 & 134.7775 & 903347.6000 & 0.0000 & 1236 \\
STERLINBANK & 0.0003 & 0.0414 & -0.0458 & 0.0137 & -0.0401 & 2.8485 & 1.5122 & 0.4695 & 1236 \\
TRANSCORP & 0.0006 & 0.0424 & -0.0458 & 0.0150 & 0.1418 & 3.9473 & 50.3551 & 0.0000 & 1236 \\
UACN & 0.0000 & 0.0414 & -0.1077 & 0.0099 & -1.5673 & 21.2002 & 17565.2100 & 0.0000 & 1236 \\
UACP & -0.0002 & 0.0422 & -0.1046 & 0.0113 & -1.0541 & 14.4561 & 6987.8470 & 0.0000 & 1236 \\
UBA & -0.0004 & 0.0422 & -0.0996 & 0.0134 & -0.4317 & 6.7215 & 751.6428 & 0.0000 & 1236 \\
UNILEVER & 0.0003 & 0.0422 & -0.0446 & 0.0092 & -0.0761 & 6.0595 & 483.2578 & 0.0000 & 1236 \\
WAPCO & 0.0003 & 0.0423 & -0.0458 & 0.0089 & -0.0149 & 7.0491 & 844.4029 & 0.0000 & 1236 \\
ZENITH & 0.0001 & 0.0421 & -0.1076 & 0.0099 & -1.0038 & 15.3208 & 8025.4370 & 0.0000 & 1236 \\
Avg & 0.0001 & 0.0514 & -0.0706 & 0.0109 & -0.1146 & 16.7190 & 51383.9938 & 0.0235 & 1236 \\
\hline
\end{tabular}

An analysis of the table reveals several points. First, the table reveals that the average stock returns for the 20 selected firms as well as the whole market is relatively low ranging from $-0.06 \%$ (Oando) to $+0.07 \%$ (Forte). 20 percent of the firms have negative returns, another 20 percent have zero returns while the remaining 60 percent have positive returns. Overall, the whole market has an insignificant positive return. The table also indicates the minimum and maximum stock returns vary from $-17.61 \%$ to $-3.97 \%$ and $3.96 \%$ to $24.87 \%$ for minimum and maximums respectively. The whole market has a minimum of $-2.41 \%$ and a maximum return of $2.3 \%$. from the descriptive statistics it is also clear that stock return on the NSE are not approximated to normal distribution since the Jarque-Bera's p-values are all lower than 0.05 (except with respect to Sterlin Bank.

The behaviour of daily returns series of the whole NSE over the period January 2010 to December 2014 is graphically stated in Figure 1.

Fig 1: Time Series Plot of Nigerian Stock Exchange daily returns

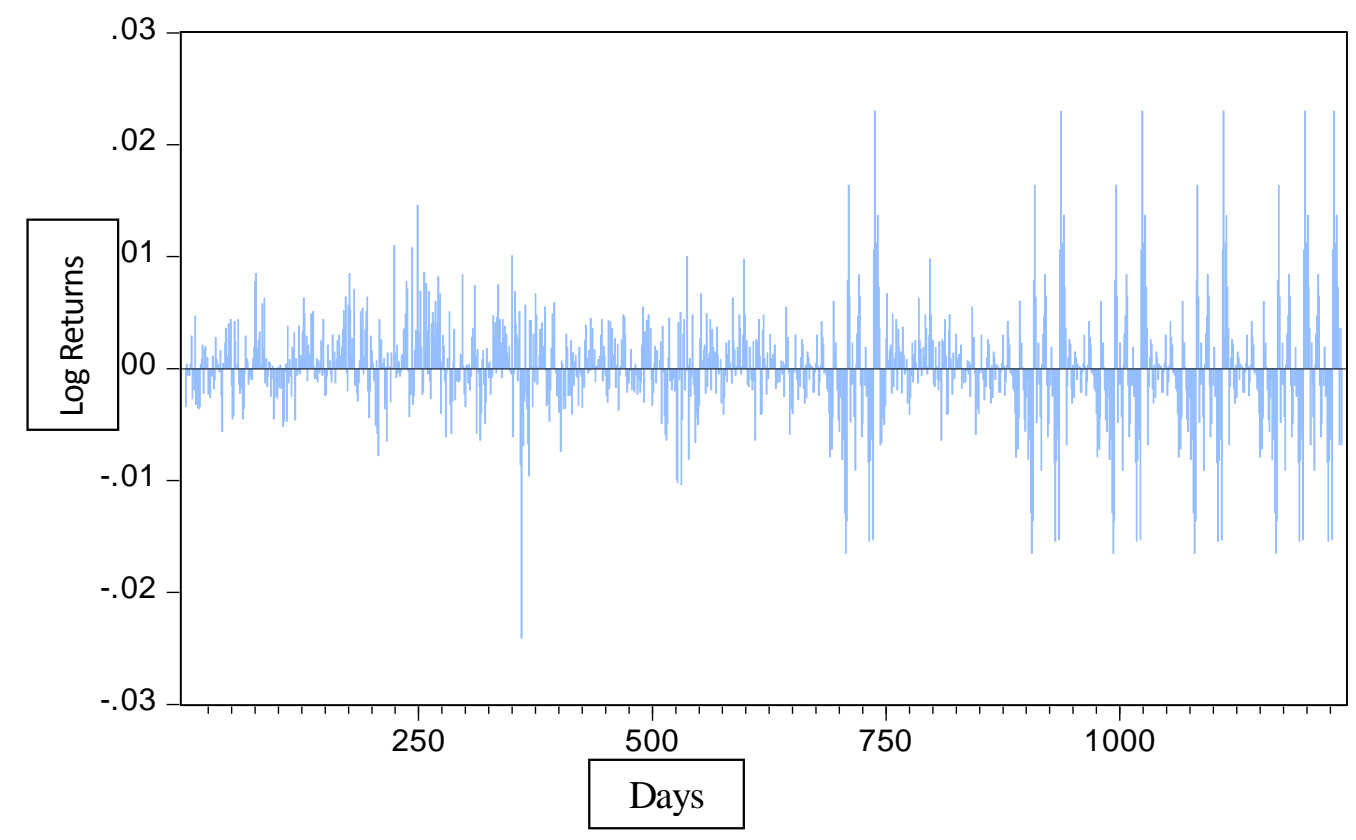

Specifically, Figure 1 indicates a high level of volatility associated with the returns in the NSE. The figure is an indication that sock returns in NSE might be randomly distributed or alternatively might be a weak form informational efficient. 
The basic purpose in this study is to test whether NSE is informational weak-form efficient. Alternatively stated, the study examines whether share returns on the NSE exhibit persistence which may be exploited to predict future price changes. In this regards autocorrelation and runs tests were conducted. The result of the autocorrelation test is presented in Table 3.

If there is no autocorrelation $\mathrm{AC}$ and PAC at all lags (lag 1, 2, $3 \ldots 15$ ) should be equal to zero and Qstatistics should be insignificant with large p-values. From the analysis it can be seen that 16 companies representing $80 \%$ of the sample have insignificant Q-statistic $(\mathrm{p}<0.05)$ even at the $15^{\text {th }}$ lag. These statistics indicate that the stock return follows a random walk on the NSE. Restated alternatively, since the $\mathrm{p}$ value is more than $5 \%$, we cannot reject the null hypothesis that the stock return on the NSE does not have serial correlation.

Table 3: Autocorrelation statistics for the daily returns of the sample firms

\begin{tabular}{|c|c|c|c|c|c|c|c|c|c|c|}
\hline Company/Lags & & 1 & 2 & 3 & 4 & 5 & $\ldots$ & 10 & $\ldots$ & 15 \\
\hline \multirow[t]{2}{*}{ ACCESS } & Q-Stat & 0.0390 & 1.4064 & 6.7616 & 8.8348 & 9.7015 & $\ldots$ & 19.0640 & $\ldots$ & 22.9910 \\
\hline & Prob & 0.8430 & 0.4950 & 0.0800 & 0.0650 & 0.0840 & $\ldots$ & 0.0390 & $\ldots$ & 0.0840 \\
\hline \multirow[t]{2}{*}{ DIAMOND } & Q-Stat & 0.0270 & 0.2260 & 3.6971 & 6.7900 & 9.5073 & $\ldots$ & 13.0110 & $\ldots$ & 15.0400 \\
\hline & Prob & 0.8700 & 0.8930 & 0.2960 & 0.1470 & 0.0900 & $\ldots$ & 0.2230 & $\ldots$ & 0.4490 \\
\hline \multirow[t]{2}{*}{ FBNH } & Q-Stat & 0.3450 & 18.0150 & 30.9440 & 31.6610 & 31.6880 & $\ldots$ & 34.1590 & $\ldots$ & 42.7090 \\
\hline & Prob & 0.5570 & 0.0000 & 0.0000 & 0.0000 & 0.0000 & $\cdots$ & 0.0000 & $\cdots$ & 0.0000 \\
\hline \multirow[t]{2}{*}{ FIDELITY } & Q-Stat & 0.0341 & 1.3515 & 4.8000 & 10.5530 & 13.0560 & $\ldots$ & 17.7430 & $\ldots$ & 21.3620 \\
\hline & Prob & 0.8530 & 0.5090 & 0.1870 & 0.0320 & 0.0230 & $\ldots$ & 0.0590 & $\ldots$ & 0.1260 \\
\hline \multirow[t]{2}{*}{ FLOURMILLS } & Q-Stat & 0.0028 & 0.4580 & 1.4193 & 1.4193 & 2.2825 & $\ldots$ & 6.6242 & $\ldots$ & 12.9190 \\
\hline & Prob & 0.9580 & 0.7950 & 0.7010 & 0.8410 & 0.8090 & $\ldots$ & 0.7600 & $\ldots$ & 0.6090 \\
\hline \multirow[t]{2}{*}{ FORTE } & Q-Stat & 0.7850 & 3.1872 & 6.1304 & 7.1552 & 10.6130 & $\ldots$ & 18.3640 & $\ldots$ & 20.8650 \\
\hline & Prob & 0.3760 & 0.2030 & 0.1050 & 0.1280 & 0.0600 & $\ldots$ & 0.0490 & $\ldots$ & 0.1410 \\
\hline \multirow[t]{2}{*}{ GTB } & Q-Stat & 0.0012 & 3.2343 & 8.3253 & 8.7560 & 13.3340 & $\ldots$ & 24.0670 & $\ldots$ & 32.4390 \\
\hline & Prob & 0.9730 & 0.1980 & 0.0400 & 0.0670 & 0.0200 & $\ldots$ & 0.0070 & $\ldots$ & 0.0060 \\
\hline \multirow[t]{2}{*}{ GUINESS } & Q-Stat & 0.0470 & 2.1133 & 3.6846 & 3.7169 & 4.2028 & $\ldots$ & 12.1190 & $\ldots$ & 19.3550 \\
\hline & Prob & 0.8280 & 0.3480 & 0.2980 & 0.4460 & 0.5210 & $\ldots$ & 0.2770 & $\ldots$ & 0.1980 \\
\hline \multirow[t]{2}{*}{ NB } & Q-Stat & 0.0305 & 3.9211 & 7.0646 & 7.4160 & 7.9499 & $\ldots$ & 15.4970 & $\ldots$ & 22.3500 \\
\hline & Prob & 0.8610 & 0.1410 & 0.0700 & 0.1150 & 0.1590 & $\ldots$ & 0.1150 & $\ldots$ & 0.0990 \\
\hline \multirow[t]{2}{*}{ NESTLE } & Q-Stat & 0.0008 & 0.1029 & 0.4867 & 0.5339 & 1.0787 & $\ldots$ & 3.7776 & $\ldots$ & 12.2880 \\
\hline & Prob & 0.9780 & 0.9500 & 0.9220 & 0.9700 & 0.9560 & $\ldots$ & 0.9570 & $\ldots$ & 0.6570 \\
\hline \multirow[t]{2}{*}{ OANDO } & Q-Stat & 0.6155 & 3.5289 & 12.3620 & 13.3210 & 14.8950 & $\ldots$ & 22.8100 & $\ldots$ & 29.9690 \\
\hline & Prob & 0.4330 & 0.1710 & 0.0060 & 0.0100 & 0.0110 & $\ldots$ & 0.0110 & $\ldots$ & 0.0120 \\
\hline \multirow[t]{2}{*}{ STERLIN BANK } & Q-Stat & 0.0000 & 0.0002 & 1.1653 & 2.0968 & 3.3494 & $\ldots$ & 10.6000 & $\ldots$ & 12.1020 \\
\hline & Prob & 0.9980 & 1.0000 & 0.7610 & 0.7180 & 0.6460 & $\ldots$ & 0.3890 & $\ldots$ & 0.6710 \\
\hline \multirow[t]{2}{*}{ STANBIC } & Q-Stat & 0.0042 & 0.0823 & 0.2456 & 0.8012 & 3.9914 & $\ldots$ & 8.8902 & $\ldots$ & 10.9770 \\
\hline & Prob & 0.9480 & 0.9600 & 0.9700 & 0.9380 & 0.5510 & $\cdots$ & 0.5430 & $\cdots$ & 0.7540 \\
\hline \multirow[t]{2}{*}{ TRANSCORP } & Q-Stat & 0.0221 & 0.1809 & 0.3397 & 0.7227 & 2.8703 & $\ldots$ & 5.4709 & $\ldots$ & 16.2470 \\
\hline & Prob & 0.8820 & 0.9140 & 0.9520 & 0.9490 & 0.7200 & $\ldots$ & 0.8580 & $\ldots$ & 0.3660 \\
\hline \multirow[t]{2}{*}{ UACN } & Q-Stat & 0.0000 & 0.0026 & 0.0582 & 2.1166 & 2.9414 & $\ldots$ & 7.0267 & $\ldots$ & 15.0330 \\
\hline & Prob & 0.9990 & 0.9990 & 0.9960 & 0.7140 & 0.7090 & $\ldots$ & 0.7230 & $\ldots$ & 0.4490 \\
\hline \multirow[t]{2}{*}{ UACP } & Q-Stat & 0.0000 & 0.0308 & 3.1543 & 3.2889 & 4.0631 & $\ldots$ & 6.0364 & $\ldots$ & 10.4240 \\
\hline & Prob & 0.9960 & 0.9850 & 0.3680 & 0.5110 & 0.5400 & $\ldots$ & 0.8120 & $\ldots$ & 0.7920 \\
\hline \multirow[t]{2}{*}{ UBA } & Q-Stat & 0.1503 & 1.6566 & 2.9030 & 5.7827 & 5.8159 & $\ldots$ & 12.7860 & $\ldots$ & 16.5950 \\
\hline & Prob & 0.6980 & 0.4370 & 0.4070 & 0.2160 & 0.3250 & $\ldots$ & 0.2360 & $\ldots$ & 0.3440 \\
\hline \multirow[t]{2}{*}{ UNILEVER } & Q-Stat & 0.0000 & 0.0000 & 0.5485 & 3.4013 & 3.4265 & $\ldots$ & 5.5687 & $\cdots$ & 15.3500 \\
\hline & Prob & 0.9950 & 1.0000 & 0.9080 & 0.4930 & 0.6350 & $\ldots$ & 0.8500 & $\ldots$ & 0.4270 \\
\hline \multirow[t]{2}{*}{ WAPCO } & Q-Stat & 0.0535 & 4.5810 & 4.6666 & 4.9935 & 5.8672 & $\ldots$ & 18.6510 & $\ldots$ & 19.5400 \\
\hline & Prob & 0.8170 & 0.1010 & 0.1980 & 0.2880 & 0.3190 & $\cdots$ & 0.0450 & $\cdots$ & 0.1900 \\
\hline \multirow[t]{2}{*}{ ZENITH } & Q-Stat & 0.0264 & 8.0600 & 14.6980 & 16.1790 & 16.3160 & $\ldots$ & 26.1350 & $\ldots$ & 33.4430 \\
\hline & Prob & 0.8710 & 0.0180 & 0.0020 & 0.0030 & 0.0060 & $\ldots$ & 0.0040 & $\ldots$ & 0.0040 \\
\hline \multirow[t]{2}{*}{ Avg } & Q-Stat & 0.1092 & 2.6070 & 5.6727 & 6.9770 & 8.3475 & $\ldots$ & 14.4200 & $\ldots$ & 20.0999 \\
\hline & Prob & 0.8367 & 0.5559 & 0.4134 & 0.3826 & 0.3592 & $\ldots$ & 0.3479 & $\ldots$ & 0.3189 \\
\hline
\end{tabular}

A complementary test was conducted using the runs test since daily returns of the selected samples are not normally distribution (see Table 2). The results of the runs test are presented in Table 4. 


\begin{tabular}{lcccccc} 
Table 4: Results for the Runs Tests \\
\hline Firms & Cases $\mathbf{0}$ & Cases $\geq \mathbf{0}$ & Total Cases & Number of Runs & $\mathbf{Z}^{\mathbf{a}}$ & p-value \\
\hline ACCESS & 554 & 682 & 1236 & 557 & -3.1855 & 0.0014 \\
DIAMOND & 555 & 681 & 1236 & 555 & -3.3112 & 0.0009 \\
FBNH & 583 & 653 & 1236 & 547 & -3.9976 & 0.0001 \\
FIDELITY & 558 & 678 & 1236 & 635 & 1.2539 & 0.2099 \\
FLOURMILLS & 296 & 940 & 1236 & 414 & -2.9090 & 0.0036 \\
FORTE & 236 & 1000 & 1236 & 303 & -7.3604 & 0.0000 \\
GTB & 558 & 678 & 1236 & 598 & -0.8718 & 0.3833 \\
GUINESS & 313 & 923 & 1236 & 382 & -6.5077 & 0.0000 \\
NB & 470 & 766 & 1236 & 504 & -4.8034 & 0.0000 \\
NESTLE & 227 & 1009 & 1236 & 297 & -7.0851 & 0.0000 \\
OANDO & 551 & 685 & 1236 & 510 & -5.8588 & 0.0000 \\
STANBIC & 445 & 791 & 1236 & 551 & -1.2086 & 0.2268 \\
STERLINBANK & 532 & 704 & 1236 & 577 & -1.7430 & 0.0813 \\
TRANSCORP & 433 & 803 & 1236 & 408 & -9.7290 & 0.0000 \\
UACP & 277 & 959 & 1236 & 404 & -2.1972 & 0.0280 \\
UBA & 585 & 651 & 1236 & 562 & -3.1526 & 0.0016 \\
UNILEVER & 336 & 900 & 1236 & 481 & -0.6701 & 0.5028 \\
WAPCO & 366 & 870 & 1236 & 500 & -1.1089 & 0.2675 \\
ZENITH & 553 & 683 & 1236 & 597 & -0.8726 & 0.3829 \\
UACN & 351 & 885 & 1236 & 482 & -1.5149 & 0.1298 \\
Avg & 439 & 797 & 1236 & 493 & -3.3417 & 0.1110 \\
\hline & & & & & &
\end{tabular}

Table 4 indicates that the stock returns of the sample companies follow a random walk. Out of the 1236 days, 439 have negative returns on average and 797 have positive or zero returns. Since the calculated p-values are more than the critical value (0.05), we fail to reject that the order of stock returns on the NSE follow a random walk. These results should however be interpreted with caution, since the zero values might be capable of influencing the results.

These results contrast the earlier findings by Afego (2012) in Nigeria. The implication is that prices in the market do not follow a predetermined pattern. The overall results suggest that NSE is informational weak-form efficient since the returns are random. The results suggest that it is difficult to consistently outperform (fool) the stock market by simply studying past information on the NSE because such information is already impounded in security prices. This result differs from the earlier studies which suggest that the market is not efficient even at the weak form. Reasons for these new findings might be the following: (1) developments in the NSE (such as the computerisation of the market) make trading and transmission of information in real time. Participants send and receive information about the market almost instantaneously. (2) The setting up of securities tribunal has facilitated quick dispensation of justice or instils discipline in the market.

\section{Conclusion}

Market efficiency is a fundamental concept in finance. It is a concept bothering on fair play in the securities market. Because the concept is so important it has been extensively tested from time to time to see if the market is informationally efficient or not. The concept of market efficiency encompasses three things; information (pricing) efficiency, operational efficiency and allocational efficiency. Our study focuses on informational efficiency. Fama (1970) states that the information efficiency is more important and consists of three levels: the weak form, the semi-strong and strong-form efficiency. This study tests the weak form market efficiency. Based on our analysis using the autocorrelation and runs test, the study found that the daily stock returns of the 20 most active stocks on the Nigerian stock market are randomly distributed. This study therefore concludes that the NSE is informational efficient in the weak form. 


\section{References}

Afego, P. (2012). Weak Form Efficiency of the Nigerian Stock Market: An Empirical Analysis (1984 - 2009). International Journal of Economics and Financial Issues, 2(3): 340-347

Akpan, O.E. (1995). Thin and Thick Capital Markets. Nigerian Journal of Social Economic Research, 1(37): 2-4.

Ayadi, O. (1984). Random Walk Hypothesis and the Behaviour of Stock Prices in Nigeria. The Nigerian Journal of Economics and Social Studies, 26(1): 57-71.

Ayentimi, D.T., Mensah, A.E. \& Naa-Idar, F. (2013). Stock Market Efficiency of Ghana Stock Exchange: An Objective Analysis. International Journal of Management, Economics and Social Sciences 2(2): 54-75.

Bachelier, L. (1900). Theory of Speculation. In Cotner, P. (Ed.). The Random Character of Stock Market Prices. Cambridge: the M.I.T Press. Pp. 17-78.

Brown, S. J. (2011). The Efficient Markets Hypothesis: The Demise of the Demon of Chance? Accounting and Finance, 51, (1), 79-95. DOI: 10.1111/j.1467-629X.2010.00366.x

Clarke J., Jandik T. \& Mandelker, G. (2000). Efficient Market Hypothesis. Retrieved from: m.e-mh.org/CIJM.pdf. May 29, 2015.

Dimson, E. \& Mussavian, M. (1998). A Brief History of Market Efficiency. European Finacial Management, 4(1): 93-193.

Fama, E. F. (1965). The Behavior of Stock Market Prices. Journal of Business, 38: 34-105.

Fama, E. F. (1970). Efficient Capital Markets: A Review of Theory and Empirical Work. Journal of Finance, 25(2): 383-417.

Fama, E. F. (1991). Efficient Capital Markets II. Journal of Finance, 46: 575-617.

Gimba, V. K. (2012). Testing the Weak-form Efficiency Market Hypothesis: Evidence from Nigerian Stock Market. CBN Journal of Applied Statistics 3(1): 117-136.

Li, X. (2008). Tests of stock market efficiency in China and Japan. Master Thesis. Stockholm: KTH Royal Institute of Technology.

Nwosa, P.I. \& Oseni, I.O. (2011). Efficient Market Hypothesis and Nigerian Stock Market. Research Journal of Finance and Accounting 2, (12): 38-46.

Okpara, G.C. (2010). Stock Market Prices and the Random Walk Hypothesis: Further Evidence from Nigeria. Journal of Economics and International Finance, 2(3): 049-057.

Olowe, R.A. (1999). Weak Form Efficiency of the Nigerian Stock Exchange Market: Further Evidence. African Development Review, 11 (1): 54-68.

Samuel, J. M. \& Yacout, M. (1981). Stock Exchange in Developing Countries. Savings and Developments, 5 (4): 309-328.

Shafi, M. (2014). Testing of Market Efficiency in the Weak-Form Taking CNX Nifty as a Benchmark Index: A Study. Journal of Finance, 2(2): 1-20.

Simons, D. \& Laryea, S. A. (2006). The Efficiency of Selected African Stock Markets. Finance India $X X(2): 553-571$.

Tijjani, B. (2010). Share Valuation and Stock Market Analysis in Emerging Markets: The Case of Nigeria. Kano: Adamu Joji Publishers. Pp. 25-99 